\title{
Factors Affect the Success of SME in Bangladesh: Evidence from Khulna City
}

\author{
Md Reaz Uddin ${ }^{1} \&$ Tarun Kanti Bose ${ }^{1}$ \\ ${ }^{1}$ Business Administration Discipline, Khulna University, Bangladesh \\ Correspondence: Tarun Kanti Bose, Business Administration Discipline, Khulna University, Bangladesh. E-mail: \\ tarun84ku@yahoo.com
}

Received: March 3, 2013

Accepted: April 2, 2013 Online Published: July 3, 2013

doi:10.5539/jms.v3n3p166

URL: http://dx.doi.org/10.5539/jms.v3n3p166

\begin{abstract}
Small and Medium Enterprises (SMEs) occupy dominant positions in economy. SMEs bear special significance for counties where density of population is very high because it offers huge employment opportunities and income generations at low cost. Considering the importance this study has strived to identify those factors contribute the success of SMEs using causal model. Data were collected from SMEs owners of the Khulna city, divisional city of Bangladesh. A total 195 respondents were finally interviewed for the study. Several factors were selected typically affect the success of SMEs from pervious literature. Important factors were identified first using rotated components matrix later regression statistics was applied to find out which are statistically significant. Business plan, channel of distribution, management skills and government support are identified statistically significant in determining success of SMEs in Khulna City.
\end{abstract}

Keywords: factors, SME success, Khulna City, Bangladesh

\section{Introduction}

Small and Medium Enterprises (SME) occupy a dominant position in any economy of world. SME activities cover all areas of business including manufacturing, mining, wholesaling, retailing, service and the like. This sector is an integral part of an economy and considered as an active engine of economic growth. Small and medium enterprises, including the tiny and 'micro' enterprises comprise virtually all (about $99.85 \%$ ) of all business enterprises outside agriculture in Bangladesh (Rahman, 2009). Small and Medium Enterprises play an important role in economy through generation of employment, contributing to the growth of GDP, embarking on innovation and stimulating other economic activities (Gamage, 2003). SMEs including micro enterprises account for some $81.2 \%$, while only $0.15 \%$ of all business enterprises employ a full $18.8 \%$ of the employment of all business enterprises outside agriculture (Rahman, 2009).

In Bangladesh approximately 6 million micro, small and medium enterprises (MSMEs), which included enterprises with up to 100 workers employing a total of 31 million people, equivalent to 40 per cent of the population of the country of age 15 years and above. SMEs consisted of primarily wholesale and retail trade and repairs (40 per cent), production and sale of agricultural goods ( 22 percent), services (15 percent), and manufacturing only (14 per cent). Contribution to GDP varies sector to sector. Manufacturing contributed the highest proportion ( 38 per cent), followed by Agriculture (24 per cent) and, closely following, wholesale and Retail Trade and Repairs (23 per cent) (Mintoo, 2006).

\section{Literature Review}

The success of SME depends on number of various factors which are multidimensional. Some factors are internal and some are external. Both affect the success but there is considerable variation in these factors identified by previous studies. Chittithaworn et al (2011) explored the business success factors of SME in Thailand based on a survey. They examined eight factors which are SMEs characteristic, management and know-how, products and services, Customer and Market, the way of doing business and cooperation, resources and finance, strategy, and external environment. They found some variables significantly affecting business success in Thailand which are SMEs characteristic, customer and market, the way of doing business and cooperation, resources and finance and external environment. Maher Al-Mahrouq (2010) in his case study on small and medium enterprise on Jordan identified some influential and positive factors affect business success. 
He ranked those according to their importance which are technical procedures and technology, structure of the firm, financial structure, marketing and productivity and human resources structure. Jasra et al (2011) examined the role of key success factors in the success of SMEs in Pakistan. They also investigated the relationship between the determinants and the success factors. They found some factors have significant relationship with success of SMEs which are financial resources, marketing strategy, technological resources, government support, business plan and entrepreneur skills. Islam, Khan and Obaidullah (2011) investigated effect of characteristics of entrepreneur and characteristics of the firm on the success of Small and Medium Enterprises in Bangladesh based on survey. They found characteristics of entrepreneurs affect the success of SMEs in Bangladesh. They found duration of operation is important factor in success. They commented that SMEs that are operated longer period have been more successful in comparison to those who have been in operation for a shorter period. Akhtar, Raees and Salaria (2011) worked on SMEs to identify the impacts of location specific factors, firm specific factors and ownership specific factors on their foreign market performance. They intended to find which has the strongest effect on success in foreign market. They found all these factors have significant effect for the success of Pakistani SMEs in the foreign markets. Temtime and Pansiri (2004) investigated the critical success factors affecting the performance and development of Small and Medium Enterprises (SMEs). They have identified number of factors critical for the success for SMEs which are product / service marketing, marketing research information, demand forecasting and analyzing, pricing policy and strategy, trained sales staff and market segmentation. They ignored some factors related to entrepreneurs and firms. Yahya et al. (2011) examined the relationships between managerial skills and success of small and medium enterprises in service sectors in Malaysia. They found number of different skills which contribute for the success of SMEs. Those skills are budgeting skills, human relations skills, business operating skills, skills to obtain share from market, management expertise skills, skills to offer special services, skills to focus on quality and design of product and services, organizational structuring skills, marketing strategy skills. These skills significantly affect SMEs success in service sectors. Saleem (2012) investigated some socioeconomic factors like age, education, experience, skills on the success of small business. He found investment, business profile; entrepreneur experience and culture are significant for the success. Anwar and Andaleeb (2007) studied some key elements to identify their contributions to the success of SMEs. They commented that the factors contribute for the success of small enterprises and large enterprises are same. Those primary common factors they identified were efficient management practices, productivity of labor and efficient financial management. They noted size of the firms directed toward attainment economies of scale.

\section{Definition of SMEs}

The definition of Small and Medium Enterprise (SME) is not fixed rather it varies countries to countries. According the Ministry of Industry, in case of manufacturing, an enterprise would be treated as small if, in today's market prices, the replacement cost of plant, machinery, structures, and other parts/components, fixtures, support utility, and associated technical services (such as turn-key consultancy), i.e. Tk. 50,000 to 1.5 crore ( 0.05 million to Tk. 15 million and / or workforce not more than 50. An enterprise would be treated as medium if, in today's market prices, the replacement cost of plant, machinery, building, structures, and other parts/components, fixtures, support utility, and associated technical services (such as turn-key consultancy), i.e Tk 1.5 crore to Tk 20 crore ( tk 15 million to Tk. 200 million and/ or workforce not more than 150. In both cases, land and building is exclude.

In case non-manufacturing, this definition is slightly different. According to Ministry of Industry, Bangladesh, An enterprise would be treated as small if the fixed capital is Tk. 50,000 to Tk.50, 00000 ( 0.05 million to Tk. 5 million and / or workforce not more than 25. An enterprise would be treated as medium if the fixed capital is Tk. 50,00000 to Tk. 10,00,00000 (5 million to Tk. 100 million and / or workforce not more than 50. In cases, land and building is excluded.

\section{Hypotheses of the Study}

In the light of above literatures the proposed hypotheses of the study are

H1: There is a significant relationship between business plan and success of SMEs.

$\mathrm{H} 2$ : There is a significant relationships between channel of distribution of products/services and success of SMEs.

H3: There is a significant relationship between management skills and success of SMEs.

H4: There is a significant relationship between use of technology and success of SMEs.

H5: There is a significant relationship between support of government and success of SMEs. 
H6: There is a significant relationship between access to capital and success of SMEs.

H7: There is a significant relationship between human resource and success of SMEs.

H8: There is a significant relationship between customer management and success of SMEs.

H9: There is a significant relationship between product/service and success of SMEs.

\section{Methodology}

A survey type of research was designed to test the hypotheses, intended to investigate the factors affect the success of SMEs, with data collected from the owners of SMEs located in Khulna City using structured survey instrument. The questions were adopted from the previous literature. A convenience sampling method was adopted to collect sample form all owners of SMEs located in Khulna City whcih is the population of this study. A group of five students from Business Administration Disciple, Khulna University was appointed to conduct the survey with 200 questionnaires from where 195 were found flawless thus used for the study.

To determine the success factor of SMEs nine independent variables of the 46 items were generated. Factor analysis was used to purify and validate those variables and their internal consistency was also examined applying reliability statistics (cronbach alpha).

A principle components factor analysis with varimax rotation was used to indentify factors explain the success of SMEs which yielded nine factors with eigen values more than 1.0 (as shown table 1). The factor analysis results further shows that these nine factors affect the success of SMEs cumulatively explain $63.29 \%$ of total variance.

Table 1. Principles components matrix

\begin{tabular}{|c|c|c|c|c|c|c|c|c|c|}
\hline \multirow{2}{*}{ Component } & \multicolumn{3}{|c|}{ Initial Eigenvalue } & \multicolumn{3}{|c|}{$\begin{array}{l}\text { Extraction Sums of Squared } \\
\text { Loadings }\end{array}$} & \multicolumn{3}{|c|}{ Rotation Sums of Squared Loadings } \\
\hline & Total & $\begin{array}{l}\% \text { of } \\
\text { Variance }\end{array}$ & $\begin{array}{l}\text { Cumulative } \\
\%\end{array}$ & Total & $\begin{array}{l}\% \text { of } \\
\text { Variance }\end{array}$ & $\begin{array}{l}\text { Cumulative } \\
\%\end{array}$ & Total & $\begin{array}{l}\% \text { of } \\
\text { Variance }\end{array}$ & $\begin{array}{l}\text { Cumulative } \\
\%\end{array}$ \\
\hline 1 & 7.239 & 17.235 & 17.235 & 7.239 & 17.235 & 17.235 & 4.775 & 11.368 & 11.368 \\
\hline 2 & 5.539 & 13.188 & 30.422 & 5.539 & 13.188 & 30.422 & 3.486 & 8.300 & 19.668 \\
\hline 3 & 3.068 & 7.304 & 37.727 & 3.068 & 7.304 & 37.727 & 3.477 & 8.279 & 27.947 \\
\hline 4 & 2.529 & 6.021 & 43.747 & 2.529 & 6.021 & 43.747 & 2.808 & 6.686 & 34.634 \\
\hline 5 & 2.124 & 5.057 & 48.804 & 2.124 & 5.057 & 48.804 & 2.673 & 6.363 & 40.997 \\
\hline 6 & 1.702 & 4.053 & 52.857 & 1.702 & 4.053 & 52.857 & 2.522 & 6.006 & 47.002 \\
\hline 7 & 1.639 & 3.903 & 56.760 & 1.639 & 3.903 & 56.760 & 2.427 & 5.778 & 52.781 \\
\hline 8 & 1.449 & 3.449 & 60.209 & 1.449 & 3.449 & 60.209 & 2.390 & 5.691 & 58.472 \\
\hline 9 & 1.294 & 3.081 & 63.291 & 1.294 & 3.081 & 63.291 & 2.024 & 4.819 & 63.291 \\
\hline
\end{tabular}

Note: Extraction Method: Principal Component Analysis

Table 2. Rotated component matrix

\begin{tabular}{|c|c|c|c|c|c|c|c|c|c|c|}
\hline & & \multicolumn{9}{|c|}{ Components } \\
\hline & & $\begin{array}{l}\text { Business } \\
\text { Plan }\end{array}$ & $\begin{array}{l}\text { Channel of } \\
\text { Distribution }\end{array}$ & $\begin{array}{l}\text { Management } \\
\text { Skills }\end{array}$ & Technology & $\begin{array}{l}\text { Government } \\
\text { Support }\end{array}$ & Capital & Personnel & $\begin{array}{l}\text { Customer } \\
\text { Management }\end{array}$ & $\begin{array}{l}\text { Product } \\
\text { /Service }\end{array}$ \\
\hline 2 & Q24 & .778 & -.050 & .034 & .184 & -.275 & .090 & .030 & .146 & .159 \\
\hline 3 & Q23 & .777 & -.133 & .092 & .163 & .058 & .125 & -.122 & .116 & -.073 \\
\hline 4 & Q21 & .716 & -.159 & .023 & -.119 & .043 & .134 & .174 & .131 & .287 \\
\hline 5 & Q20 & .628 & -.029 & .163 & .143 & -.133 & .090 & -.049 & .204 & .220 \\
\hline 6 & Q06 & .608 & .123 & .061 & .034 & .419 & .267 & -.023 & -.032 & .106 \\
\hline 7 & Q38 & .489 & .053 & .020 & .097 & .047 & -.059 & .152 & -.017 & -.203 \\
\hline 8 & Q11 & .474 & .221 & .195 & .225 & .208 & .069 & -.354 & .026 & -.277 \\
\hline 9 & Q08 & -.036 & .884 & .096 & .028 & .024 & .112 & .072 & .079 & .148 \\
\hline 10 & Q09 & -.101 & .873 & .127 & -.048 & .117 & .018 & -.094 & -.005 & .086 \\
\hline 12 & Q10 & -.116 & .729 & .114 & .097 & .218 & -.034 & -.176 & -.100 & -.061 \\
\hline 13 & Q29 & -.018 & .145 & .775 & .116 & .139 & .141 & .157 & .076 & .034 \\
\hline 14 & Q30 & .191 & -.002 & .765 & .023 & .159 & .166 & .063 & .185 & .119 \\
\hline
\end{tabular}




\begin{tabular}{|c|c|c|c|c|c|c|c|c|c|c|}
\hline 15 & Q28 & .074 & .017 & .756 & -.026 & .100 & .197 & .086 & .053 & .021 \\
\hline 16 & Q31 & -.034 & .047 & .693 & .225 & .049 & .070 & -.015 & .109 & .027 \\
\hline 17 & Q32 & .095 & .268 & .504 & -.033 & .141 & .083 & -.444 & .063 & .153 \\
\hline 18 & Q33 & .190 & .165 & .503 & .090 & .084 & .008 & -.463 & .012 & .103 \\
\hline 19 & Q14 & .023 & .062 & .169 & .771 & .115 & .122 & .214 & -.014 & -.034 \\
\hline 20 & Q13 & -.013 & -.007 & .087 & .740 & -.103 & .175 & .254 & -.035 & .120 \\
\hline 21 & Q12 & .235 & .038 & .017 & .664 & .047 & .155 & -.059 & .092 & -.004 \\
\hline 22 & Q36 & .227 & .041 & .187 & .483 & .064 & -.018 & -.187 & .004 & .352 \\
\hline 23 & Q26 & -.145 & .100 & .335 & -.004 & .745 & -.036 & -.044 & -.039 & -.015 \\
\hline 24 & Q25 & -.358 & .332 & .229 & .040 & .654 & .066 & -.129 & .063 & .110 \\
\hline 25 & Q05 & .287 & .307 & .138 & -.058 & .543 & .033 & .165 & .023 & .197 \\
\hline 26 & Q27 & -.383 & .201 & .317 & .111 & .499 & -.001 & -.077 & .032 & .024 \\
\hline 27 & Q14 & .121 & -.116 & -.001 & .408 & .436 & .099 & -.057 & .088 & .192 \\
\hline 28 & Q40 & .011 & .111 & -.066 & -.002 & .435 & .077 & -.266 & .251 & -.216 \\
\hline 29 & Q17 & .252 & .080 & .161 & .150 & -.028 & .794 & .023 & -.103 & .093 \\
\hline 30 & Q18 & .347 & .041 & .148 & .173 & -.011 & .783 & -.035 & -.059 & -.049 \\
\hline 31 & Q16 & .028 & .135 & .146 & .236 & .014 & .654 & -.049 & .023 & .266 \\
\hline 32 & Q19 & -.016 & -.025 & .209 & .006 & .177 & .626 & .209 & -.012 & -.207 \\
\hline 33 & Q37 & -.096 & -.184 & .015 & -.012 & -.039 & .194 & .655 & -.063 & .099 \\
\hline 34 & Q39 & .112 & .054 & .226 & .155 & .036 & -.076 & .596 & .001 & -.122 \\
\hline 35 & Q41 & .367 & -.009 & -.069 & .380 & -.228 & .146 & .529 & .121 & .018 \\
\hline 36 & Q42 & .272 & -.030 & .037 & .443 & -.056 & -.025 & .526 & .040 & .061 \\
\hline 37 & Q44 & .152 & -.027 & .156 & .035 & -.054 & -.139 & -.067 & .809 & .139 \\
\hline 38 & Q45 & .183 & -.057 & .067 & -.013 & .155 & -.064 & -.030 & .717 & .060 \\
\hline 39 & Q46 & -.107 & .021 & .144 & .227 & -.107 & .093 & .213 & .683 & .150 \\
\hline 40 & Q43 & .252 & .055 & .077 & -.106 & .139 & -.011 & -.108 & .663 & -.230 \\
\hline 41 & Q34 & .214 & -.001 & .084 & .110 & -.063 & .073 & .046 & .077 & .784 \\
\hline 42 & Q35 & .018 & .225 & .145 & .114 & .278 & -.012 & -.049 & .057 & .699 \\
\hline
\end{tabular}

\section{Research Finding}

Table 3 (appendix) shows the reliability statistics of measures used in this study. Reliabilities were checked and they fall between 0.60 and 0.88 , which is satisfactory for study that is exploratory in nature (Nunnally, 1978). All factors except technology and customer management have scores higher that 0.60 although those two have scores close to the accepted level. The overall scores of the factors were 0.719 which indicates that the reliability is reasonably high thus, depicting high internal consistency among the measurement items.

Table 3. Regression statistics

\begin{tabular}{lll}
\hline Variable & Standardized Beta & Alpha \\
\cline { 2 - 4 } Business Plan & $.268^{* *}$ & .856 \\
Channel of Distribution & $.288^{* *}$ & .877 \\
Management Skills & $.228^{*}$ & .810 \\
Technology & .076 & .587 \\
Government Support & $.422^{* *}$ & .705 \\
Access to Capital & .116 & .788 \\
Personnel & -.140 & .609 \\
Customer Management & .099 & .55 \\
Product/Service & -.041 & .689 \\
R Square & .40 & \\
F Value & $12.145^{* *}$ & \\
Durbin-Watson & 1.954 & \\
\hline
\end{tabular}

Note: $* * \mathrm{p}<.001, * \mathrm{p}<.05$

Regression model fits the data the well with $\mathrm{F}$ value $12.14(\mathrm{p}<.001)$. $\mathrm{R}$ square value .40 indicates that $40 \%$ variation in the success of SME is explained by the independent variables used in this study. Business plan, 
channel of distribution, management skills and government support are statistically significant in determining success of SMEs in Khulna City. The results also indicate government support, channel of distribution, business plan are the strong indicators followed by management skills. (Table 3)

Durbin Watson value (1.954) falls in acceptance range thus there is not auto correlation problem in the model. F value (12.45) is statistically significant which indicates data were fit the model well. (Table 3, appendix)

Table 4 (appendix) presents the collinearity statistics. The variance inflation factor and tolerance are within accepted range $(\mathrm{VIF}=1-10$, Tolerance $=0.1-1.0)$. These results indicate there is no multicollinearity problem in this model.

Table 4. Collinearity statistics

\begin{tabular}{lll}
\cline { 2 - 3 } Variables & Tolerance & VIF $^{*}$ \\
\hline Business Plan & .769 & 1.300 \\
Channel of Distribution & .958 & 1.043 \\
Management Skills & .785 & 1.274 \\
Use of Technology & .810 & 1.234 \\
Government Support & .934 & 1.070 \\
Access to Capital & .949 & 1.053 \\
HR & .704 & 1.420 \\
Customer Management & .946 & 1.057 \\
Improved Product/Service & .756 & 1.324 \\
\hline
\end{tabular}

Note: *Variance Inflation Factor

\section{Result and Discussion}

In order to evaluate the success factor of SMEs, analysis has been done to evaluate the relationship of SME success with some key variables in the form of Business Plan, Channel of Distribution, Management Skills, Technology, Government Support, Access to Capital, Personnel, Customer Management and Product/Service. Result shows that business plan, Channel of Distribution, Management Skills and government support has strong positive correlation with the success factors of SMEs where as Personnel and Product and Service has bit of negative correlation and finally the rest three variables Technology, Customer Management and Access to Capital has slight positive correlation. This outcome reveals interesting reading as far as the success factors of the SMEs of Khulna City is concern.

Business plan is the basic premise of the success of virtually each and every business operation and the case of SMEs are no exception. It is definitely an important ingredient and thus has strong long term influence regarding the efficiency and effectiveness of business operations of the SMEs. Therefore, s suitable and appropriate business plan is always the key and the outcome of this study certainly came in support of that notion. The SME owner of the city seems to be agreed upon on the fact that they need a sound and timely plan for gaining sustainable success in their operation. The analysis and results of the study also expose the fact that the biggest success factor of the SME operation in the city is the Government support as far as the perception and opinions of the SME owners are concern. This picture is a common one particularly in developing countries where government support plays a big role in flourishing the SMEs and making the success track a smoother one. There are mainly three types of activities government can initiate and take for helping the operation of the SMEs. Those are stimulatory, supporting and sustaining activities. Those acts are targeted in the areas of business initiation, business continuation and business sustainable success. Therefore by carrying out those acts governments and policy makers plays a key part in the development activities of SME business success. The outcome of this study also stands in support of that notion.

Management Skills and Channels of Distribution also found to be key performance indicators of the SME success of Khulna City. The score has showed significant correlation among Management Skills, Channels of Distribution and SME success. Distribution channel is always a key issue for each and every type of business firms as it is a vital part of the value chain and effectiveness of the value chain virtually depends on this. SME owners of Khulna City also perceive the same principle and the study outcome articulated the same thing. Management skills also perceived to be important variables for the success factors of the SMEs. This is primarily because SME owners normally undertake the management tasks by themselves and therefore they reckon that management skills are always essential ingredients for their virtual success. 
A significant outcome of this study is the relationship between personnel and SME success factors. This study portrayed that there is negative correlation between this two variables. It is an interesting outcome considering the fact that personnel are essential for business operation. A closer look deep into the context exposes the basic reasons behind it. SME owners of the city normally like to carry out most of the tasks of their business and seldom like to adopt more workforces. They also perceive that the efficiency of their operation is likely to increase if the tasks are done by themselves and will be decreased if carried out by somebody else. That is why the relationship is negative and conveys some important policy implications for the firms and policy makers as well.

Finally, the current research also articulated the fact that Technology, Customer Management and Access to Capital has there is slightly positive correlation with SME success. This outcome is quite different from the global research as most of those detected contrasting result. However, it shows bit of traditional and ancient business model and preferences for the SME owners of the city and also of Bangladesh. This outcome is also not unexpected as the country is still far behind in compare to global standard of modern business operation. That's I why they do not necessarily feel the same importance of technology and customer management in compare to SMEs of Europe or the US. However, access to capital score is quite unexpected considering the fact that it is basically the major conditions for starting and continuing the business. But, it also represents improvement in the capital and finance sector of the country and that is why SMEs are not facing the same degree of difficulty in compare to the situation of 10 or 15 years back.

\section{Conclusion and Implications}

This underlying research study articulated few important implications and thus put automatic emphasized on few corrective measurements for the policy makers of the city and country which is needed to be incorporated and upgraded sooner than later for flourishing the SME sector in the city. This scientific research paper has successfully evaluated the most important success factors for the initiation, continuation and sustainability of the SMEs of the city. Those important factors needed to ensured and also cared and nurtured in proper ways for boosting up the businesses of the SMEs. It needed to be assured that they can get proper counseling and consulting for making business plan, government support and efficient distribution channel. Government can take steps for ensuring the service and also can establish SME center for helping the SMEs in various aspects including making a fruitful and conducive business plan and also can motivate the SMEs for establishing networking among themselves and thus can establish a sound combined distribution network. Unwillingness towards adopting modern technology is quite evident among the SMEs, therefore in order to upgrade their operation and gaining global competencies government need to take action and also includes the SME sector into the government broad planning of the Digital Bangladesh concept. Finally, lack of interest to recruit more personnel and also lack of trust on employees is a common notion among SMEs which is needed to be eliminated for their business expansion as well as modernization and sustainable attainment of core competencies.

\section{References}

Akhtar, S., Raees, R., \& Salaria, M. R. (2011). International Conference on Technology and Business Management. Shaheed Zulfiqar Ali Bhutto Institute of Science \& Technology, Islamabad, March 28-30.

Anwar, S. F., \& Andaleeb, S. S. (2007). Factors Contributing to Small and Medium Enterprise (SME) Growth: A Theoretical Perspective. International Review of Business Research Papers, 3(5), 44-53.

Chittithaworn, C., Islam, M. A., Keawchana, T., \& Yusuf, D. H. M. (2011). Factors Affecting Business Success of Small \& Medium Enterprises (SMEs) in Thailand. Asian Social Science, 7(5), 180-190. http://dx.doi.org/10.5539/ass.v7n5p180

Gamage, A. S. (2003). Small and Medium Enterprise Development in Sri Lanka: A Review. Retrieved July 24, 2012, from http://202.11.2.113/SEBM/ronso/no3_4/aruna.pdf

Islam, M. A., Khan, M. A., Obaidullah, A. Z. M., and Alam, M. S. (2011). Effect of Entrepreneur and Firm Characteristics on the Business Success of Small and Medium Enterprises (SMEs) in Bangladesh. International Journal of Business and Management, 6(3), 289-299.

Jasra, J. M., Khan, M. A., Hunjra, A. I., Rehman, R. A., \& Rauf, I. A. (2011). Determinants of Business Success of Small and Medium Enterprises. International Journal of Business and Social Science, 2(20), 274-280.

Maher, A. M. (2010). Success Factors of Small and Medium-Sized Enterprises (SMEs): The Case of Jordan. Anadolu University Journal of Social Sciences, 10, 1-16. 
Mintoo, A. A. (2006). SME in Bangladesh. CACCI Journal, 1, 1-19.

Nunnally, J. C. (1978). Psychometric Theory (2nd ed.). New York: McGraw-Hill.

Rahman, M. S. (2009). Role of SMEs Export Growth in Bangladesh. Retrieved July 24, 2012, from http://www.cacci.org.tw/Journal/2010Volume1/page71-89.pdf

Saleem, M. A. (2012). The impact of socio-economic factors on small business success. Geografia Online Malaysia Journal of Society and Space, 8(1), 24-29.

Temtime, Z. T., \& Pansiri, J. (2004). Small Business Critical Success/Failure Factors in Developing Economies: Some Evidences from Botswana. American Journal of Applied Science, 1(1), 18-25. http://dx.doi.org/10.3844/ajassp.2004.18.25

Yahha, A. Z., Fatt, C. K., Othman, A. S., Rahman, I. A., \& Moen, J. (2011). Management skills and entrepreneurial success of small and medium enterprises (SMEs) in the services sector. African Journal of Business Management, 5(26), 10410-10418.

\section{Copyrights}

Copyright for this article is retained by the author(s), with first publication rights granted to the journal.

This is an open-access article distributed under the terms and conditions of the Creative Commons Attribution license (http://creativecommons.org/licenses/by/3.0/). 